Creative commons User License: CC BY-NC-ND

Abstracted by: EBSCOhost, Electronic Journals Service (EJS),

Google Scholar, Directory of Open Access Journals (DOAJ),

Journal Seek, Scientific Commons,

Food and Agricultural Organization (FAO), CABI and Scopus
Journal of Agricultural Extension

Vol. 20 (2) December, 2016

ISSN(e): 24086851; ISSN(Print); 1119944X

http://journal.aesonnigeria.org

http://www.ajol.info/index.php/jae

Email: editorinchief@aesonnigeria.org

\title{
Cocoa Farmers Attitude towards Utilisation of Integrated Pest Management in Edo and Ogun States of Nigeria
}

http://dx.doi.org/10.4314/jae.v21i1.6

\section{Uwagboe, Eghosa Osas}

Department of Economics and Extension

Cocoa Research Institute of Nigeria, P.M.B. 5244, Idi-Ayunre, Ibadan

Email: eghosauwagboe1@gmail.com

Phone:08055447597

\section{Famuyiwa, Busayo Solomon}

Department of Economics and Extension

Cocoa Research Institute of Nigeria, P.M.B. 5244, Idi-Ayunre, Ibadan

Email: famuyiwabusayo@gmail.com

Phone: 08033978146

\section{Agbebaku, Endurance Eniola Omiunu}

Department of Economics and Extension

Cocoa Research Institute of Nigeria, P.M.B. 5244, Idi-Ayunre, Ibadan

Email: talk_2_endy@yahoo.com

Phone:08065279091

\begin{abstract}
The study examined cocoa farmers' attitude towards the utilization of integrated pest management (IPM) in Edo and Ogun States of Nigeria. In Edo State, 60 respondents were randomly selected out of 100 trained cocoa farmers. Random selection of 60 respondents from registered cocoa farmers that were not trained in IPM was done in the Ogun State Agricultural Development Programme. Interview schedule was used to obtain data on respondents' characteristics, cocoa yield and attitude of respondents towards IPM. Data were analysed using descriptive statistics and Chi-square. The majority (73.3\%) of trained and $56.7 \%$ of untrained had formal education. The total respondents result showed that $49.2 \%$ had favourable attitude. There was a significant relationship between both the attitude of trained respondents $\left(X^{2}=5.72\right.$, $P<0.05)$ and their cocoa bean yield of and the attitude of untrained respondents $\left(X^{2}=5.64, P<0.05\right)$ and their cocoa bean yield. The mean yield of trained respondents $(1436.3 \pm 1196.4 \mathrm{~kg})$ significantly differed from that of the untrained respondents (1209.3 $\pm 524.3 \mathrm{~kg})$, which shows that IPM training had much impact on farmer's cocoa yield, hence, untrained farmers need training in IPM.
\end{abstract}

Keywords: Cocoa farmers, Integrated Pest Management.. 
Creative commons User License: CC BY-NC-ND

Abstracted by: EBSCOhost, Electronic Journals Service (EJS),

Google Scholar, Directory of Open Access Journals (DOAJ),

Journal Seek, Scientific Commons,

Food and Agricultural Organization (FAO), CABI and Scopus
Journal of Agricultural Extension

Vol. 20 (2) December, 2016

ISSN(e): 24086851; ISSN(Print); 1119944X

http://journal.aesonnigeria.org

http://www.ajol.info/index.php/iae

Email: editorinchief@aesonnigeria.org

\section{Introduction}

The main insect pests and diseases of cocoa are brown mirids; Sahlbergella singularis and black mirids; Distantiella theobroma. Several factors such as high infestation of insect pest, high infection of diseases, inadequate funds for inputs, improper processing methods, inadequate labour supply, high dependence on chemicals and ageing cocoa farms and farmers are responsible for the dwindling situation in cocoa production in Nigeria. Among these factors, insect pests and diseases have become a major threat to increase in cocoa production75\% loss in Nigeria (Adegbola, 1989).

Babara (2007) reports that pesticide poisoning remains commonplace in developing countries despite international initiatives addressing this problem. The predominance of peasant farmers in cocoa cultivation, who do not easily adhere to recommended improved pest control practices such as pruning, regular weeding, removal of diseased and damaged pods at the end of the harvesting season and application of recommended types and dosage of agro-chemicals, contributes in no small measure, to the reduction in productivity of cocoa farms in Nigeria. The attitude of these farmers could affect the use of Integrated Pest Management (IPM). Hence, this study addressed the environment in which these various recommended improved pest control practices are being utilized and cocoa farmers' attitude towards the utilization of Integrated Pest Management in cocoa farms.

Findings from this study will assist in identifying problems associated with cocoa protection practices among farmers for research and extension focus. This will also create opportunities for farmers and other stakeholders in cocoa production to appreciate the need to adopt improved technology such as IPM in insect pests and diseases management and de-emphasize use of chemicals as major control by cocoa farmers. It will also bring about having IPM package that is effective for cocoa farmers.

The Individual Innovativeness theory (Rogers, 1995) states that individuals who are predisposed to being innovative will adopt an innovation earlier than those who are 
Creative commons User License: CC BY-NC-ND

Abstracted by: EBSCOhost, Electronic Journals Service (EJS),

Google Scholar, Directory of Open Access Journals (DOAJ),

Journal Seek, Scientific Commons,

Food and Agricultural Organization (FAO), CABI and Scopus
Journal of Agricultural Extension

Vol. 20 (2) December, 2016

ISSN(e): 24086851; ISSN(Print); 1119944X

http://journal.aesonnigeria.org

http://www.ajol.info/index.php/iae

Email: editorinchief@aesonnigeria.org

less predisposed. The Figure 1 shows the bell shaped distribution of Individual Innovativeness and the percentage of potential adopters theorized to fall into each category. On one extreme of the distribution are the Innovators. Innovators are the risk takers and pioneers who adopt an innovation very early in the diffusion process. On the other extreme are the Laggards who resist adopting an innovation until rather late in the diffusion process, if ever. This theory relates innovativeness with adoption.

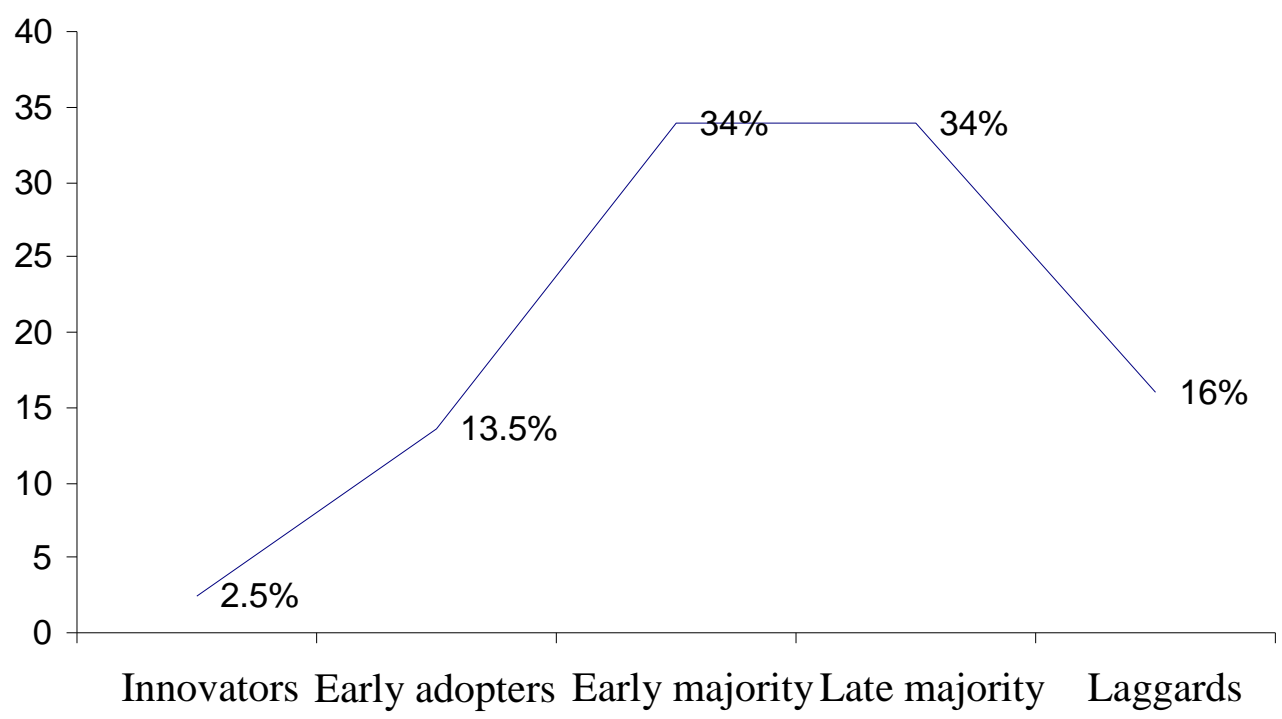

Fig. 1: Line graph showing categories of individual innovativeness and percentages within each category

Source: Rogers, 1995.

The dearth of information on the effect that cocoa farmers' attitude towards the utilization of IPM can have on cocoa production thus led to this study. This study was therefore prosecuted by addressing the following research questions:

i. what are the selected personal characteristics of the cocoa farmers in the study area?

ii. what is the attitude of cocoa farmers towards the use of IPM techniques in the study area?

iii. .what are the levels of yield of the cocoa farmers in the study area? 
Creative commons User License: CC BY-NC-ND

Abstracted by: EBSCOhost, Electronic Journals Service (EJS),

Google Scholar, Directory of Open Access Journals (DOAJ),

Journal Seek, Scientific Commons,

Food and Agricultural Organization (FAO), CABI and Scopus

\section{Objectives of the study.}

Journal of Agricultural Extension

Vol. 20 (2) December, 2016

ISSN(e): 24086851; ISSN(Print); 1119944X

http://journal.aesonnigeria.org

http://www.ajol.info/index.php/iae

Email: editorinchief@aesonnigeria.org

The general objective of this study was to assess the effect of cocoa farmers' attitude on the utilisation of IPM on cocoa production in the study area. Specific objectives were to:

i. identify the personal characteristics of cocoa farmers in the study area;

ii. ascertain the attitude of cocoa farmers towards the use of IPM techniques in the study area; and

iii. ascertain the level of cocoa bean yield of cocoa farmers in the study area.

\section{Hypotheses of the Study}

1. There is no significant relationship between respondents' personal characteristics and their cocoa bean yield.

2. There is no significant relationship between respondents' attitude towards IPM and their cocoa bean yield

\section{Methodology}

\section{The Study Area}

The study areas were Ogun and Edo States which fall under medium cocoa producing areas in Nigeria. According to the categorization of the National Cocoa Development Committee (2012), the medium cocoa producing areas are; Edo, Ogun, Oyo, Ekiti, Abia, Delta and Akwa-lbom. The two states were purposively selected due to their similarities in cocoa production.

\section{Population and Sampling}

The study population consisted of cocoa farmers that have received training and those that have not received training in Edo state and Ogun state, respectively.

In Edo state a systematic sampling technique was used to select sixty (60) farmers out of 100 IPM trained farmers of Farmers Field School (FFS) organised by 
Creative commons User License: CC BY-NC-ND

Abstracted by: EBSCOhost, Electronic Journals Service (EJS),

Google Scholar, Directory of Open Access Journals (DOAJ),

Journal Seek, Scientific Commons,

Food and Agricultural Organization (FAO), CABI and Scopus
Journal of Agricultural Extension

Vol. 20 (2) December, 2016

ISSN(e): 24086851; ISSN(Print); 1119944X

http://journal.aesonnigeria.org

http://www.ajol.info/index.php/iae

Email: editorinchief@aesonnigeria.org

STCP/ITA. A Multi-stage sampling procedure was used to select farmers that were not trained on IPM from Ogun State Agricultural Development Programme (OGADEP). The first stage involved selection of one zone (Ikenne zone) out of the 4 zones in the programme, with simple random sampling technique. Secondly, 2 blocks (Obafemi and Isara blocks) were selected out of the four blocks in the zone. The third stage was purposive selection of 4 cells out of 23 cells based on cocoa producing areas and 15 respondents were selected from each of the 4 cells (Orile Oke, Abujana, Alapako Oni and Sora Baale) giving a total of sixty (60) respondents for the study.

\section{Table 1: ADP structure used for sampling respondents in Ogun State}

\begin{tabular}{llllllcl}
\hline States & $\begin{array}{l}\text { Actual } \\
\text { zones }\end{array}$ & $\begin{array}{l}\text { Zone } \\
\text { selecte } \\
\mathrm{d}\end{array}$ & $\begin{array}{l}\text { Actual } \\
\text { No. of } \\
\text { Blocks }\end{array}$ & $\begin{array}{l}\text { Block } \\
\text { selecte } \\
\mathrm{d}\end{array}$ & $\begin{array}{l}\text { Actual } \\
\text { cells }\end{array}$ & $\begin{array}{l}\text { Cells selected Respondents selecte } \\
\text { in 2 blocks }\end{array}$ & $\begin{array}{l}\text { in } 4 \text { cells } \\
\text { (15 farmers per cell) } \\
\text { from EA's list }\end{array}$ \\
\hline Ogun 4 & 1 & 4 & 2 & 23 & 4 & 60 \\
\hline
\end{tabular}

\section{Instrument for Data Collection}

A structured questionnaire was used to elicit information from the cocoa farmers in relation to the study objectives. The questionnaire was divided into three sections as follows; (A) selected personal characteristics, (B) attitude of respondents towards IPM utilisation, (C) cocoa bean yield.

\section{Results and Discussion}

\section{Selected Personal Characteristics}

\section{Age of Respondents}

Age is a factor thought to affect adoption. It is said to be a primary latent characteristic in adoption decisions. Table 2 reveals that the trained, $81.7 \%$ were between the age range of 41 and 60 years which indicates that most of them were still in their prime age and would be ready to learn and apply the skill of IPM techniques in their farms. On the whole, majority $(60.8 \%)$ of the respondents were in the age bracket of 41 and 60 years. Half of the untrained $(50.0 \%)$ were above 60 years and $40.0 \%$ were between 41 and 60 while $10.0 \%$ between 21 and 40 . This is an indication that half of the cocoa farmers who did not receive the training are 
Creative commons User License: CC BY-NC-ND

Abstracted by: EBSCOhost, Electronic Journals Service (EJS),

Google Scholar, Directory of Open Access Journals (DOAJ),

Journal Seek, Scientific Commons,

Food and Agricultural Organization (FAO), CABI and Scopus
Journal of Agricultural Extension

Vol. 20 (2) December, 2016

ISSN(e): 24086851; ISSN(Print); 1119944X

http://journal.aesonnigeria.org

http://www.ajol.info/index.php/iae

Email: editorinchief@aesonnigeria.org

ageing and few youths are involved in cocoa farming which could affect IPM techniques negatively as some of the techniques are labour intensive.

However, there is contention on the direction of the effect of age on adoption. Age was found to positively influence adoption of sorghum in Burkina Faso (Adesiina and Baidu-Forson, 1995), IPM on peanuts in Georgia (McNamara, Wetzstein, and Douce, 1991), and chemical control of rice stink bug in Texas.

\section{Sex of Respondents}

The Table 2 shows that $89.2 \%$ of the respondents were males, of which $90.0 \%$ were trained and $88.3 \%$ were untrained. This is an indication that more males were involved in cocoa farming than the females. The present findings indicate that cocoa farming was a male dominated profession and that most farms in the study area were owned by males. This could be due to the limitations women have in acquiring land for tree crop cultivation in Nigeria.

\section{Respondents' Years of Experience in Cocoa Farming}

Table 2 shows that more of the trained farmers (55.0\%) have longer years of experience than the untrained farmers (33.3\%). The overall picture indicates that $44.2 \%$ had above 30 years' experience which shows that the farmers have moderate years of experience in cocoa farming. This could have positive effect on IPM practices. This means that some might be expected to have considerable knowledge about insect pest and disease control of their cocoa trees. The old age of the farmers translates to high farming experience as majority could have started farming at an early age. This is in agreement with Amos (2007) whose findings suggested that farming experience is important for day-to-day running of the farming activities including IPM practices, as cocoa cultivation is very tasking.

\section{Educational Qualification of Respondents}

In Fig. 2 sixty-five percent of the total respondents had formal education among the trained $(73.3 \%)$ and untrained $(56.7 \%)$ which indicates that some untrained also have the ability to receive information on IPM since they are educated while those 
Creative commons User License: CC BY-NC-ND

Abstracted by: EBSCOhost, Electronic Journals Service (EJS), Google Scholar, Directory of Open Access Journals (DOAJ), Journal Seek, Scientific Commons,

Food and Agricultural Organization (FAO), CABI and Scopus
Journal of Agricultural Extension

Vol. 20 (2) December, 2016

ISSN(e): 24086851; ISSN(Print); 1119944X

http://journal.aesonnigeria.org

http://www.ajol.info/index.php/iae

Email: editorinchief@aesonnigeria.org

that are trained would apply the skill and knowledge gained in the training of IPM properly. Studies that have sought to establish the effect of education on adoption in most cases relate it to years of formal schooling (Feder and Slade, 1984; Tjornhom, 1995;). Generally, education is thought to create a favourable mental attitude for the acceptance of new practices, especially of information-intensive and managementintensive practices (Waller, Henderson, Stinner and Welty, 1998; Caswell, Fuglie., Ingram, Jans and Kascak, 2001). IPM is frequently stated to be a complex technology (Pimentel, 1986; Boahene, Snijders, and Folmer, 1999).

Table 2: Distribution of respondents on selected personal characteristics

\begin{tabular}{llll}
\hline Characteristics & Trained Percentage $(\mathrm{n}=60)$ & $\begin{array}{l}\text { Untrained Percentage } \\
(\mathrm{n}=60)\end{array}$ & $\begin{array}{c}\text { Total Percentage } \\
(\mathrm{n}=120)\end{array}$ \\
\hline Age (Years) & & & 8.4 \\
$21-40$ & 6.7 & 10.0 & 60.8 \\
$41-60$ & 81.7 & 40.0 & 30.8 \\
$>60$ & 11.6 & 50.0 & 100.0 \\
Total & 100.0 & 100.0 & \\
Sex & & & 89.2 \\
Males & 90.0 & 88.3 & 10.8 \\
Females & 10.0 & 11.7 & 100.0 \\
Total & 100.0 & 100.0 & 5.0 \\
Years of farming experience & & & 25.0 \\
1-10 & 5.0 & 5.0 & 25.8 \\
$11-20$ & 16.7 & 33.3 & 44.2 \\
$21-30$ & 23.3 & 28.3 & $\mathbf{1 0 0 . 0}$ \\
$>30$ & 55.0 & 33.3 & $\mathbf{1 0 0 . 0}$ \\
Total & $\mathbf{1 0 0 . 0}$ & & \\
\hline
\end{tabular}

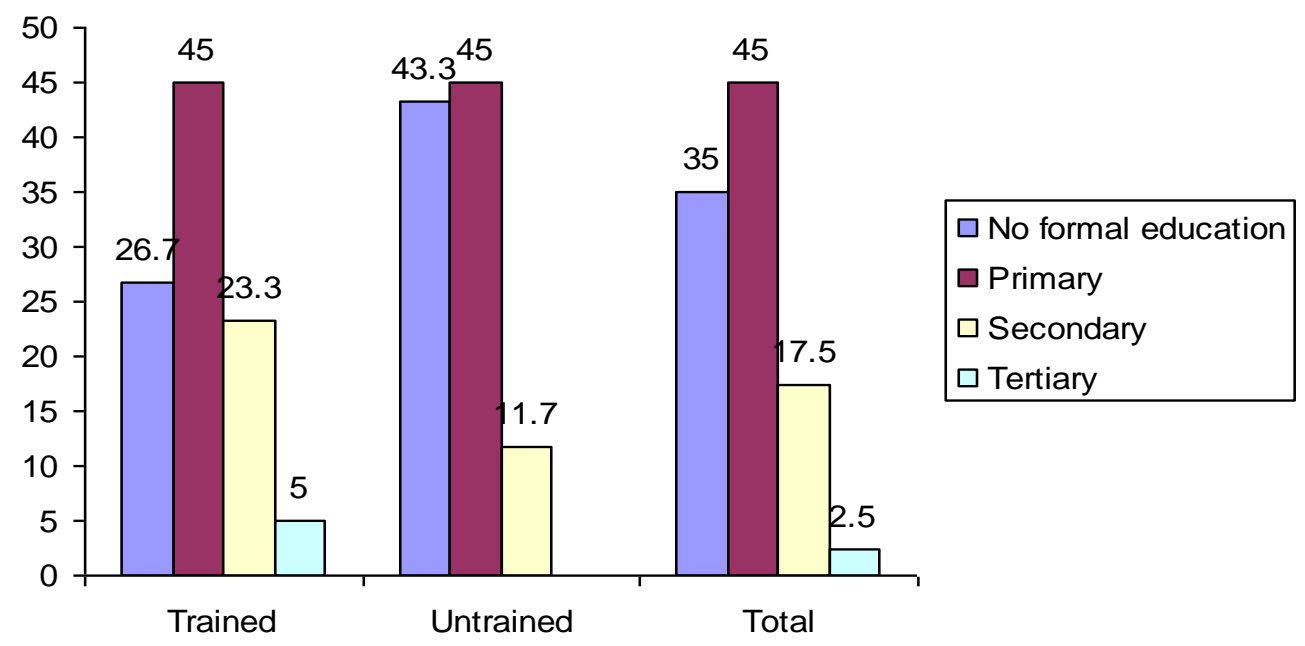

Figure 2: Distribution of educational status of respondents Source: Field Survey, 2014 
Creative commons User License: CC BY-NC-ND

Abstracted by: EBSCOhost, Electronic Journals Service (EJS),

Google Scholar, Directory of Open Access Journals (DOAJ),

Journal Seek, Scientific Commons,

Food and Agricultural Organization (FAO), CABI and Scopus
Journal of Agricultural Extension

Vol. 20 (2) December, 2016

ISSN(e): 24086851; ISSN(Print); 1119944X

http://journal.aesonnigeria.org

http://www.ajol.info/index.php/iae

Email: editorinchief@aesonnigeria.org

\section{Respondents' Farm Size}

Table 3 shows that $51.7 \%$ of the trained had farm size between 6 and 10 ha, $43.3 \%$ had $1-5$ ha, while only $5.0 \%$ had farm size greater than 10 ha. For the untrained $85.0 \%$ own $1-5$ ha while only $15.0 \%$ own farm size between 6 and 10 ha and none of them have farms above 10 ha. The overall picture shows that $64.2 \%$ of the respondents own 1-5 ha.

This implies that the majority of the farmers are small holder farmers, which may make it easy for them to adopt IPM technologies. Cultural practices such as manual weeding which is labour intensive, would not be a stress for the respondents. This finding is in agreement with Amos (2007) who observed that farmers own an average farm size of six hectares that are scattered in different locations in the locality. This farm size led to an average output of $1348.1 \mathrm{~kg}$. This is relatively small compared to potential figures of over two tonnes obtainable elsewhere. According to Agbongiarhuoyi et. al. (2013) this is a reflection of small holdings common among Nigerian and West African farmers. This may be related to the age of the farms as most farms in Ondo State are bedevilled by old age.

Table 3: Frequency distribution of respondents' farm sizes.

\begin{tabular}{|c|c|c|c|}
\hline Farm size & $\begin{array}{l}\text { Trained } \\
\text { Percentage }(n=60)\end{array}$ & $\begin{array}{l}\text { Untrained } \\
\text { Percentage }(n=60)\end{array}$ & $\begin{array}{c}\text { Total } \\
\text { Percentage }(n=120)\end{array}$ \\
\hline 1-5 Ha & 43.3 & 85.0 & 64.2 \\
\hline $6-10 \mathrm{Ha}$ & 51.7 & 15.0 & 33.3 \\
\hline$>10 \mathrm{Ha}$ & 5.0 & - & 2.5 \\
\hline Total & 100.0 & 100.0 & 100.0 \\
\hline
\end{tabular}

Source: Field Survey, 2014

\section{Categories of Respondents' Attitude Towards IPM Utilisation.}

Twenty-two attitudinal scores were constructed with positively and negatively worded statements. Five point Likert=type scale of $S A=5, A=4, U=3, D=2, S D=1$ for positively worded statements and $S D=5, D=4, U=3, A=2, S A=1$ for negatively worded 
Creative commons User License: CC BY-NC-ND

Abstracted by: EBSCOhost, Electronic Journals Service (EJS),

Google Scholar, Directory of Open Access Journals (DOAJ),

Journal Seek, Scientific Commons,

Food and Agricultural Organization (FAO), CABI and Scopus
Journal of Agricultural Extension

Vol. 20 (2) December, 2016

ISSN(e): 24086851; ISSN(Print); $1119944 X$

http://journal.aesonnigeria.org

http://www.ajol.info/index.php/iae

Email: editorinchief@aesonnigeria.org

statements were used to calculate the mean to categorize the respondents into favourable, undecided and unfavourable attitude. The total scores for all the statements range between 22 and 110 for each respondent.

Table 4 reveals that most $(61.7 \%)$ of the trained were favourably disposed to IPM utilisation while $35.0 \%$ were unfavourable and $3.3 \%$ undecided. Also, the result shows that $36.7 \%$ of the untrained were favourably disposed to IPM utilisation while $5.0 \%$ were undecided and $58.3 \%$ unfavourable. The total respondents result shows that $49.2 \%$ were favourable while $46.6 \%$ were unfavourable and $4.2 \%$ undecided. The favourable disposition of the respondents implies that there were some benefits derived from utilization of IPM. Farmers' perception of the harmful effect of chemicals did not influence farmers' decisions in regard to IPM technology adoption in spite of farmers' high knowledge about this issue. A plausible explanation would be that these farmers do not consider environmental and health impacts important considerations when choosing farming practices. A similar result was also found in the analysis of adoption of non-chemical methods for controlling olive pests in Albania (Daku, 2002).

Table 4: Frequency distribution of respondents' attitude towards utilization of IPM

\begin{tabular}{lccc}
\hline Attitude & $\begin{array}{c}\text { Trained } \\
\text { Percentage }(\mathrm{n}=60)\end{array}$ & $\begin{array}{c}\text { Untrained } \\
\text { Percentage }(\mathrm{n}=60)\end{array}$ & $\begin{array}{c}\text { Total } \\
\text { Percentage } \mathrm{n}=120)\end{array}$ \\
\hline Favourable & 61.7 & 36.7 & 49.2 \\
Undecided & 3.3 & 5.0 & 4.2 \\
Unfavourable & 35.0 & 58.3 & 46.6 \\
Total & 100.0 & 100.0 & 100.0 \\
\hline
\end{tabular}

Source: Field Survey 2014

Yield of the Respondents 
Creative commons User License: CC BY-NC-ND

Abstracted by: EBSCOhost, Electronic Journals Service (EJS),

Google Scholar, Directory of Open Access Journals (DOAJ),

Journal Seek, Scientific Commons,

Food and Agricultural Organization (FAO), CABI and Scopus
Journal of Agricultural Extension

Vol. 20 (2) December, 2016

ISSN(e): 24086851; ISSN(Print); 1119944X

http://journal.aesonnigeria.org

http://www.ajol.info/index.php/iae

Email: editorinchief@aesonnigeria.org

If farmers' price continues to stagnate while labour and the cost of other inputs continue to rise, it would become less profitable to adopt the IPM package. However, if the farmer price is raised enough to enable farmers to realize returns that are considerably higher than $100 \%$, farmers would be motivated to adopt the IPM package, provided the required inputs are available to them. Based on the mean of $1436.3 \mathrm{~kg}$ those that had a mean greater than or equal to the mean were regarded as respondents with high yield of cocoa while those that had less than the mean were respondents with low yield. The Table 5 reveals that $55.0 \%$ of the trained and $36.7 \%$ of untrained had high yield while $45.0 \%$ of the trained and $63.3 \%$ of the untrained had low yield. In a similar study Dormon (2007) found out that the extent of yield increase seems to depend on the sustained effort of removing diseased pods from the fields and other cultural practices controlling weeds, removing mistletoe and epiphytes and managing shade.

Table 5: Frequency distribution of respondents' yield

\begin{tabular}{lclcc}
\hline $\begin{array}{l}\text { Categories of } \\
\text { respondents' } \\
\text { Yield }(\mathrm{kg})\end{array}$ & $\begin{array}{c}\text { Trained } \\
\text { Percentage } \\
(\mathrm{n}=60)\end{array}$ & Categories of Yield $(\mathrm{kg})$ & $\begin{array}{l}\text { Untrained } \\
\text { Percentage } \\
(\mathrm{n}=60)\end{array}$ & $\begin{array}{c}\text { Total } \\
\text { Percentage } \\
(\mathrm{n}=120)\end{array}$ \\
\hline High $(\geq 1436.3)$ & 55.0 & High $(>1209.3 \mathrm{~kg})$ & 36.7 & 45.8 \\
Low $(\leq 1436.3)$ & 45.0 & Low $(<1209.3 \mathrm{~kg})$ & 63.3 & 54.2 \\
Total & $\mathbf{1 0 0 . 0}$ & Total & $\mathbf{1 0 0 . 0}$ & $\mathbf{1 0 0 . 0}$ \\
\hline
\end{tabular}

Source: Field survey 2014 Mean: $($ Trained $)=1436.3 \mathrm{~kg}$; (Untrained $)=1209.3 \mathrm{~kg}$

\section{Relationship Between Personal Characteristics of the Respondents and their Cocoa Bean Yield.}

Table 6 reveals that significant relationship exists between $\operatorname{sex}\left(X^{2}=5.4545, P \leq 0.05\right)$, Education ( $\left.X^{2}=11.4190, P \leq 0.05\right)$, marital status $\left(X^{2}=3.9581, P \leq 0.05\right)$, cocoa farmers' association $\left(X^{2}=7.2163, P \leq 0.05\right)$ and the yield of the trained while only education $\left(X^{2}=12.0136, P \leq 0.05\right)$ shows significant relationship with the yield of the untrained. This implies that more males in the family could increase cocoa bean yield by 
Creative commons User License: CC BY-NC-ND

Abstracted by: EBSCOhost, Electronic Journals Service (EJS),

Google Scholar, Directory of Open Access Journals (DOAJ),

Journal Seek, Scientific Commons,

Food and Agricultural Organization (FAO), CABI and Scopus
Journal of Agricultural Extension

Vol. 20 (2) December, 2016

ISSN(e): 24086851; ISSN(Print); 1119944X

http://journal.aesonnigeria.org

http://www.ajol.info/index.php/iae

Email: editorinchief@aesonnigeria.org

utilizing IPM techniques. This result is supports the findings of Bonabana-Wabbi (2002) which stated that positive coefficient on the gender variable indicates that males were more likely to adopt celosia than females.

Table 6: Relationship between personal characteristics of the respondents and their Cocoa bean yield.

\begin{tabular}{lllllll}
\hline \multirow{2}{*}{ Variables } & Trained & \multicolumn{3}{c}{ Untrained } \\
Sex & $\mathrm{X}^{2}$ & $\mathrm{DF}$ & $\mathrm{P}$ & Decision & $\mathrm{X}^{2}$ & $\mathrm{DF}$ \\
Education & 5.4545 & 1 & 0.0195 & $\mathrm{~S}$ & 0.2236 & 1 \\
& 11.4190 & 4 & 0.0222 & $\mathrm{~S}$ & 12.0136 & 3 \\
\hline
\end{tabular}

${ }^{*} P \leq 0.05$ Source: Field survey, 2014

\section{Relationship Between the Attitude of Respondents and their Cocoa Bean Yield}

Table 7 reveals that there was a significant relationship between the attitude of respondents and their cocoa bean yield $\left(X^{2}=5.72, P<0.05\right)$. This implies that the cocoa bean yield differs with the attitude of the respondents.

Patel (2007) findings concluded that majority (85.00 per cent) of the farmers had low to medium nature of favourable attitude towards IPM strategy. The characteristics of the farmers like age and farming experience were negative while, level of education; extension contact and income were positively correlated with their attitude towards integrated pest management strategy and bean yield.

Table 7: Relationship between the attitude of the respondents and their Cocoa bean yield

\begin{tabular}{lcc|ll}
\hline & & \multicolumn{2}{l}{ Untrained } \\
\hline Variables & Df & $\mathrm{X}^{2}$ value & Df & $\mathrm{X}^{2}$ value \\
\hline $\begin{array}{l}\text { Attitude of } \\
\text { respondents }\end{array}$ & 2 & $5.72^{*}$ & 2 & $5.64^{*}$ \\
\hline
\end{tabular}

${ }^{*} P \leq 0.05$. Source: Field Survey, 2014 
Creative commons User License: CC BY-NC-ND

Abstracted by: EBSCOhost, Electronic Journals Service (EJS),

Google Scholar, Directory of Open Access Journals (DOAJ),

Journal Seek, Scientific Commons,

Food and Agricultural Organization (FAO), CABI and Scopus

\section{Conclusion and Recommendation}

The trained respondents had favourable disposition while untrained respondents had unfavourable disposition towards IPM utilisation. The average yield of trained farmers was higher than that of the untrained. Youth should be encouraged to take up cocoa farming to enhance sustainability. Establishment of Farmers Field School (FFS) in all the cocoa producing states in Nigeria to facilitate the training of farmers on IPM technology which will increase adoption of this technology and farmers income. The farmers need to be supported to increase their hectare of cocoa farms. Old farms have to be rehabilitated to enhance yield and income. Women should be encouraged to grow cocoa and they should be given access to farm land for tree crops.

\section{References}

Adegbola, M. O. K. (1989). Recent developments in the studies of diseases of cocoa, Theobroma cacao L. in Nigeria. pp.76-88. In Progress in Tree Crop Research. Cocoa Research Institute Nigeria Ibadan.

Adesiina, A. A. and Baidu-Forson, J. (1995). "Farmers' Perceptions and Adoption of New Agricultural Technology: Evidence From Analysis in Burkina Faso and Guinea, West Africa." Journal of Agricultural Economics. 13:1-9

Agbongiarhuoyi, A. E., Abdulkarim, I. F., Fawole, O. P., Obatolu, B. O., Famuyiwa, B. S.and Oloyede, A. A. (2013). Analysis of Farmers' Adaptation Strategies to Climate Change in Cocoa Production in Kwara State. Journal of Agricultural Extension. 17(1): 10-22

Amos, T. T. (2007). An Analysis of Productivity and Technical Efficiency of Smallholder Cocoa Farmers in Nigeria. Journal of Social Science., 15(2): 127-133

Boahene, K., T. Snijders, A. B., and Folmer, H. (1999). An integrated socioeconomic analysis of innovation adoption: the case of hybrid cocoa in Ghana. Journal of Policy Modeling 21(2):167-184.

Bonabana, J., Taylor, D. B., Kasenge, V., Bashaasha, B. and Erbaugh, M.J. (2001). "Assessing the Economic Impacts of IPM CRSP Strategies on Groundnut Diseases in Kumi-Uganda." Annual Report, IPM CRSP.

Caswell, M., K. Fuglie., C. Ingram., S. Jans and Kascak, C. (2001). Adoption of Agricultural production practices: Lessons learned from the US. Department of Agriculture area studies project. Washington DC. US Department of Agriculture. Resource Economics Division, Economic Research service, Agriculture Economic Report No. 792. January. 
Creative commons User License: CC BY-NC-ND

Abstracted by: EBSCOhost, Electronic Journals Service (EJS),

Google Scholar, Directory of Open Access Journals (DOAJ),

Journal Seek, Scientific Commons,

Food and Agricultural Organization (FAO), CABI and Scopus
Journal of Agricultural Extension

Vol. 20 (2) December, 2016

ISSN(e): 24086851; ISSN(Print); $1119944 X$

http://journal.aesonnigeria.org

http://www.ajol.info/index.php/iae

Email: editorinchief@aesonnigeria.org

Daku, L. (2002). "Assessing farm-level and aggregate economic impacts of olive integrated pest management programs in Albania." PhD. Thesis. Virginia Polytechnic Institute and State University.

Dormon E. N. A. (2007). From a technology focus to innovation development The management of cocoa pests and diseases in Ghana. PhD Thesis. University of Ghana, Accra, Ghana.

Feder, G. and Slade,R. (1984). "The acquisition of information and the adoption of new Technology." American Journal of Agricultural Economics.. 66:312-320.

McNamara, K. T., Wetzstein, M.E. and Douce, G.K. (1991). "Factors Affecting Peanut Producer Adoption of Integrated Pest Management." Review of Agricultural Economics. 13:129-139.

Patel, M.C., Chauhan N. B. and Korat D.M. (2007). Consequence of Farmers' Attributes on their Attitude Towards Integrated Pest Management Strategy. Arnataka Journal of Agricultural Science 20 4: 797-799.

Pimentel, D. (1986). Some Aspects of Integrated Pest Management. Department of Entomology, Cornell University, Ithaca, NY.

Waller, B. E., Hoy., C. W., Henderson, J. L., Stinner, B. and Welty, C. (1998). "Matching Innovations with Potential Users: A Case Study of Potato IPM practices." Agriculture, Ecosystems and Environment. 70:203-215. 